\section{Pravdiuk N., Plakhtii T.}

\title{
DEVELOPMENT OF THE BASIC THEORETICAL BASIS OF ACCOUNTING INFORMATION OUALITY
}

Розглянуто причини відсутності парадигми якості облікової інформацї в умовах свогодення. Запропоновано структуру базових теоретичних засад якості облікової інформації. Виділено і обгрунтовано базові теоретичні конструкиї парадигми якості облікової інформачії. Визначено взаємозв'язки між базовими теоретичними конструкціями парадигми якості облікової інформації. Виділено імперативи побудови якісної облікової системи на основі використання комунікаційного niдxодy.

Ключові слова: якісний підхід, якість в бухгалтерському обліку, якість облікової інформації, парадигма обліку, парадигма якості облікової інформащіі.

\section{Introduction}

In order to form a unified vision for the further qualitative development of the enterprise's accounting system in the context of the development of a national accounting subculture, it is necessary to apply modern approaches to building a quality system that will make it possible to use existing developments in this field and ensure the formation of an information system and generate qualitative accounting information. Improvement of accounting information quality used in making managerial decisions, allows to obtain additional economic benefits and, on the whole, will accelerate the pace of development of the national economy.

In addition, another factor that determines the need for research in the field of improvement of accounting information quality is the variability of the enterprise system under the influence of internal and external factors that is the subject of accounting. In the context of adaptation of the accounting system to such changes, and given that the latter is designed to perform complex processes of transforming accounting information using the available tools ( 8 classical elements of the accounting method), the methodology for assessment of accounting information quality should be improved in accordance with changes in the functioning of the control object and its information support system.

\section{The object of research and its technological audit}

In order to increase the effectiveness of management decisions made by users on the basis of accounting information, the latter must meet the established level of quality. The object of research accounting information quality, as a category of accounting that is at the initial stage of its development and needs improvement. The appeal to the category of accounting information quality is associated with the wide application of a qualitative approach in the management of economic systems [1] and the gradual penetration into the system of international accounting regulation [2]. That is why it is necessary to formulate and justify the theoretical basis of accounting information quality that should be used both in the development of the national accounting system and accounting systems at specific enterprises in Ukraine.

\section{The aim and objectives of research}

The aim of research is to identify and substantiate the basic theoretical foundations of accounting information quality. To achieve this aim, the following tasks are defined:

1. To identify the structural elements of the theoretical foundations of accounting information quality.

2. To determine and substantiate the basic theoretical constructs of the accounting information quality paradigm and establish the relationship between them.

3. To identify the main elements of accounting information quality paradigm based on the application of the Kuhn's approach.

\section{Research of existing solutions of the problem}

The problems of applying a qualitative approach in accounting are paid attention to domestic and foreign researchers. The necessity of development of theoretical bases of accounting based on application of the qualitative approach is grounded in [3]. The question of the essence, methodology, assessment and reasons for the need to ensure the quality of accounting information is investigated in [4-6]. Philosophical aspects of applying a qualitative approach in accounting are reflected in [7]. Problems of the quality of profit are considered in [8-10] and ways of raising its level are justified. The order of application of the paradigmatic method for studying the dynamics of scientific knowledge is the subject of work [11]. Conceptual foundations for the formation of accounting information quality are disclosed in $[2,12,13]$. The structural elements of the modern paradigm of quality management are reflected in [1]. However, complex proposals to develop a basic theoretical basis for accounting information quality based on the application of a qualitative approach in accounting are absent, which requires research in this direction. 


\section{Methods of research}

To solve the problems, the following methods are used: analysis and synthesis, a systematic approach, qualitative approach, mathematical modeling, Kuhn's paradigmatic method.

\section{Research results}

Accounting as a science that studies the patterns of information reflection of the economic activity of an enterprise through the use of accounting tools should develop in the direction of improvement of accounting system quality, which, as a rule, concerns the problem of improvement of accounting information quality. As a result, today individual scientists [3] note that the main purpose of accounting is to provide quality information to external and internal users for making sound economic decisions.

In the formation of any system of scientific knowledge, in particular, accounting information quality, its fundamental principles must first be singled out, with the help of which the most essential properties and relations of the economic activity of the enterprise are fixed. The development of a set of interrelated laws and categories to explain the features of the functioning of such system of scientific knowledge indicates the emergence of concepts and theories that is a prerequisite for the formation of a scientific paradigm.

The issue of accounting information quality, in comparison with other pressing problems of the development of the enterprise's accounting system, despite its relevance since the appearance of accounting as a separate branch of scientific knowledge (the end of the XV century) to our days, has not been sufficiently studied. The research existing in this field did not entail the formation of a fullfledged paradigm, which served as an exemplary result and a means of limiting the development of individual theories and concepts that contradict its basic position.

One of the main reasons for this situation is the existence of a significant number of elements of the accounting system, against which a qualitative approach and the imperfection of approaches to their assessment and interpretation of its results by the subjects responsible for the quality management process in the enterprise can be applied. In particular, in 1982, one of the first researchers in the field of accounting, drew attention to the problem of accounting information quality, noted that quality is an important attribute of accounting information, however, it can't be easily measured, and on the whole it is not entirely consistent with the characteristics of the firm [10]. Accordingly, the author outlined the range of problems in accounting information quality with the permission and in our days: development of theoretical foundations of accounting information quality; search of effective tools for its measuring; determination of accounting information quality theory in the system of accounting scientific knowledge.

Given the insufficient solution of the above problems in today's conditions, special attention needs to be given to an analysis of the theoretical aspects of accounting information quality, taking into account the existing leading developments in this field and taking into account the traditions of scientific research of the national accounting school.
At present, the main aim of the development of accounting as a science is the need to form an ideal accounting system, to ensure the generation of an information product of the appropriate quality [7]. Development of an ideal accounting system will contribute to strengthening the status of accounting in the society as a socio-economic institution that will contribute to improve the management of the national economy and individual enterprises.

Proceeding from this approach, idealization presupposes the need to search for the most effective ways of designing and building of accounting system that could be used as a model for the implementation of these processes in the enterprise and improve the effectiveness of scientific analysis of the accounting system to improve existing accounting practices.

To build an effective quality management system of accounting information, it is necessary to formulate its basic theoretical bases, to differentiate between the available different types of theoretical constructs (concepts, models, theories, etc.) and formulate a general system of theoretical knowledge in this field. As part of the basic theoretical foundations of accounting information quality, it is proposed to distinguish two main levels - paradigmatic and conceptual (Fig. 1).

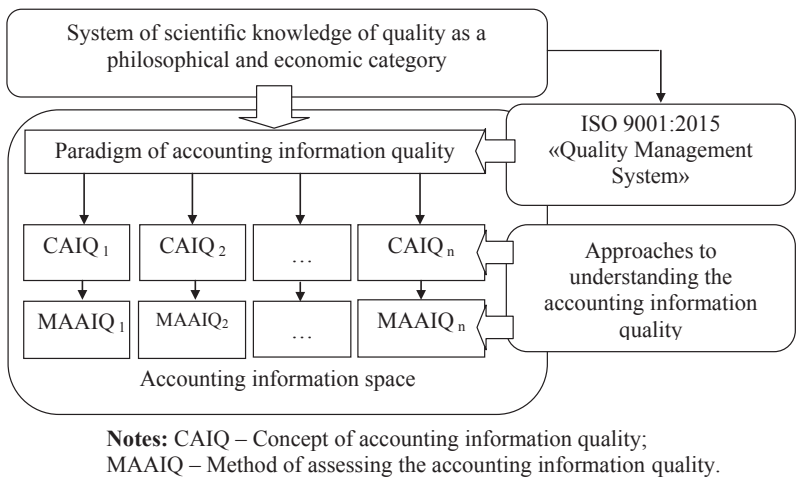

Fig. 1. Theoretical basis of accounting information quality (author's development)

The totality of the theoretical foundations of accounting information quality of the paradigmatic and conceptual level (Fig. 1) constitute the accounting information space that serves as the basis for building a system of scientific knowledge in the field of accounting information quality.

Paradigmatic level. The basis of any system of scientific knowledge is the paradigm that T. S. Kuhn defines as a disciplinary matrix consisting of four basic elements (symbolic generalizations, metaphysical assumptions, values, exemplary research results) that form both unity and function [11]. That is, it is a definite system of generally accepted theoretical and methodological attitudes and concepts that scientists of the same sphere of scientific research adhere to. The components of this paradigm are considered scientific guidelines and limitations, which should be taken into account in the implementation of scientific research in the field of accounting information quality.

Today, it can state the absence of the established paradigm of accounting information quality that indicates an insufficient level of theoretical research in this area and causes the need for scientific research. The formation of such paradigm is influenced by the development level of scientific knowledge system of quality as a philosophical 
and economic category, that is, the development of the modern paradigm of quality management. Change of the approaches of scientists to an understanding of the essence of quality and the methodology of its management and evaluation leads to a change in paradigms. This means that the available knowledge of the quality management specialists about the content and the order of implementation of this process cease to correspond to reality that hinder the progressive development of a single business process or the enterprise as a whole.

In our opinion, the current quality paradigm, which has a decisive influence on the formation of the accounting information quality paradigm, is disclosed in the ISO 9001:2015 standard «Quality Management System», built on the basis of the European directives and where uniform standards for the management system structure are defined. The quality management system implemented in this standard, which was developed by representatives of 95 countries around the world, is an example of building an ideal model or organization management ideology, in which the accounting system of an enterprise takes the appropriate place. This position is also confirmed by the fact that in some educational institutions (for example, [1]) the discipline «Modern Quality Management Paradigm» is studied on the basis of ISO 9001 standards system.

Based on the provisions of ISO 9001:2015 «Quality Management System», the following components of the accounting information quality paradigm can be identified and justified (Table 1).

Table 1

Basic theoretical constructs of the accounting information quality paradigm

\begin{tabular}{|l|l|}
\hline Name of construct & \multicolumn{1}{|c|}{ Characteristic } \\
\hline Object & Accounting information \\
\hline $\begin{array}{l}\text { Accounting informa- } \\
\text { tion quality }\end{array}$ & $\begin{array}{l}\text { A degree to which a set of inherent characteristics } \\
\text { of accounting information meets the requirements } \\
\text { of users }\end{array}$ \\
\hline $\begin{array}{l}\text { Characteristics of ac- } \\
\text { counting information } \\
\text { quality }\end{array}$ & $\begin{array}{l}\text { A distinctive feature of accounting information that can } \\
\text { be inherent or appropriated, qualitative or quantitative }\end{array}$ \\
\hline User requirement & $\begin{array}{l}\text { There is a need or expectation, which is usually } \\
\text { assumed is specific or common practice for the } \\
\text { enterprise) or is mandatory }\end{array}$ \\
\hline
\end{tabular}

The relationship between the selected basic theoretical constructs of the accounting information quality paradigm is shown in Fig. 2.

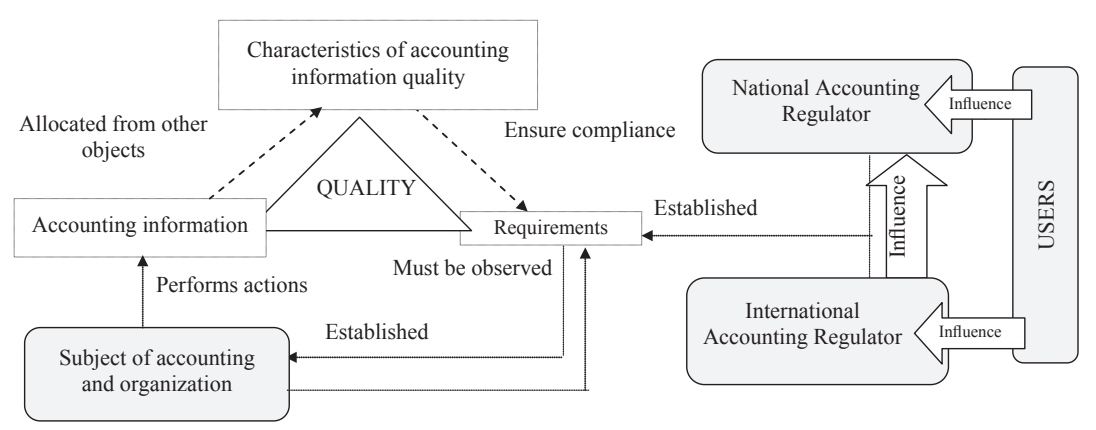

Fig. 2. Relationship between the basic theoretical constructs of the accounting quality paradigm (author's development)
The above relationship shows that accounting information quality is the degree of compliance with the characteristics of accounting information, over which the entity conducts and maintains accounting in order to meet the needs or expectations of users with established requirements. The qualitative level of accounting information is determined on the basis of comparison of the requirements established to it with the characteristics obtained as a result of the implementation of actions by the relevant actors. Under the actions that are carried out by the entities involved in accounting, it means a set of accounting procedures performed to compile accounting records and ensure the implementation of the main functions and tasks of accounting using the classical methodological tools (8 elements of accounting). Under the actions that are carried out by the subjects of accounting organization, it means a set of works and methods for their implementation with a view to building a system for processing accounting information and presenting it to interested users.

The requirements, according to which the qualitative level of accounting information is determined, are established by the national and international accounting regulators. According to paragraph 2 of Art. 6 of the Law of Ukraine «On Accounting and Financial Reporting in Ukraine», the regulation of the methodology of accounting and financial reporting is carried out by the Ministry of Finance of Ukraine, which approves national accounting provisions (standards), other regulatory legal acts on accounting and financial reporting [12]. Accordingly, the Ministry of Finance of Ukraine is the national accounting regulator, which actions depend both on the formation of an approach to understanding accounting information quality within the national accounting environment, and the procedure for determining the qualitative level of accounting information. In addition, the two data indicators (understanding the nature of accounting information quality and the procedure for its determination) also affects the activities of the International Accounting Standards Board, which members are responsible for the development and publication of IASB and their interpretations. This is determined by the fact that starting from the reporting periods of 2012, for individual domestic enterprises, it became necessary to compile financial statements and consolidated financial statements according to IASB, which is determined depending on the type of enterprise and the type of economic activity, the list of which is set by the Cabinet of Ministers of Ukraine, or what can happen at will.

The European Parliament and the Council of the European Union, which drafted and published the Directive $2013 / 34 / \mathrm{EU} \ll$ On annual and consolidated financial statements and related reports», are also included in the composition of international regulators which influence on the accounting legislative process in Ukraine is mediated. In connection with the need to bring the domestic legislation closer to the European one, in accordance with the Association Agreement with the EU, there was a need to implement the 
provisions of Directive 2013/34/EU in the system of national accounting legislation, which is also confirmed by one of the orders of the Cabinet of Ministers of Ukraine [13]. Accordingly, the standards for regulating the implementation of the accounting process developed by the European Parliament and the Council of the European Union also determine the set of requirements that must be taken into account when determining the accounting information quality.

In addition to influence of the international and national level of regulation of the accounting system, the quality of accounting information also depends on the activities of professional accounting organizations and on the activities of the entity conducting and organizing accounting at the enterprise level, both ensure compliance with the requirements set by regulators, and themselves can formulate a system of internal standards and requirements, aimed at ensuring the accounting information quality within the existing international and national accounting standards.

Based on the above, it can be determined that the application of a qualitative approach can be carried out at different levels of the accounting system and can be regulated by various instruments (Table 2).

Tahle 2

Levels of application of qualitative approach in accounting and quality control means

\begin{tabular}{|l|l|}
\hline \multicolumn{1}{|c|}{ Control levels } & \multicolumn{1}{c|}{ Control means } \\
\hline National Accounting System & $\begin{array}{l}\text { Conceptual framework or legislative acts } \\
\text { (principles, qualitative characteristics) }\end{array}$ \\
\hline $\begin{array}{l}\text { Professional accounting or- } \\
\text { ganizations }\end{array}$ & Code of Professional Ethics \\
\hline Enterprise & $\begin{array}{l}\text { Internal standardization of accounting. Order } \\
\text { on accounting policy }\end{array}$ \\
\hline
\end{tabular}

Note: author's development.

In the process of regulating the quality of information generated by the accounting system, the state, professional accounting organizations and entities responsible for organizing and maintaining accounting at a particular enterprise (head, chief accountant, auditor, etc.) participate. Thus, in order to obtain a high-quality accounting information product that will meet the needs of users, it is necessary to apply an integrated approach that involves the development of mechanisms for the formation of high-quality accounting reports both at the level of the national accounting system and at the level of a specific enterprise by ensuring the rational organization of the accounting system.

The main consumer of accounting information quality are users who aspire to be confident in the ability of regulators and subjects of management and organization of accounting to ensure the supply of accounting information with a proper level of quality. They are directly involved in the activities of national and international regulatory accounting system, affecting the process of development of content and form of financial statements by including the representatives of organizations representing the different types of users of the bodies which determine the policy regulators. For example, in the composition of the Supervisory Board of the IASB Foundation, which provides the interface between the capital market regulators and accounting control, representatives of organizations representing the main groups of accounting information users (International Organization of Securities Commissions, the Basel Committee on Banking Supervision, the Securities and Exchange Commission etc.) are included. The structure of the Methodological Council for Accounting at the Ministry of Finance of Ukraine also included representatives of the main groups of accounting information users working in relevant institutions and organizations (Department of Structural Statistics and Finance Statistics of Enterprises of the State Statistics Service of Ukraine, Department of Analysis, Strategy and Development of Legislation of the National Securities Commission Securities and the Stock Market, Accounting Department of the National Bank of Ukraine, Association of Ukrainian experts; Department of Methodology, Standards of regulation and Supervision of Financial Institutions of the National Commission, carrying out state regulation of financial services markets, etc.), which provide the necessary relationship between the requirements of users and national accounting regulation system.

On the basis of above-mentioned basic theoretical constructs of accounting information quality paradigm it is possible to allocate its basic elements using an approach to understanding the essence of the paradigm proposed by T. S. Kuhn:

1. Symbolic generalizations are defined as expressions that can be converted without any special effort into a logical form of the type $(x)(e)(z) F(x, y, z)$ [10]. In our opinion, the main symbolic generalization of the current accounting information quality paradigm is the existence of a functional relationship between the quality of accounting information and the level of satisfaction of users' needs and expectations, which can be reflected in the following formula:

$$
\bar{y}=\sum_{i=0}^{n}(a+b) \cdot x_{n}
$$

where, $\bar{y}$ - the level of accounting information quality; $a$ - the level of users' satisfaction of accounting information; $b$ - the level of satisfaction of users' expectations of accounting information; $x$ - types of users of accounting information; $n$ - the number of users of accounting information.

This formula reflects that a particular value of the level of users' needs and expectations of accounting information corresponds to a certain value of the quality level of accounting information. On its basis, a general concept of improvement of accounting information quality at domestic enterprises can be formulated.

2. To the metaphysical assumptions that determine the most fundamental methodological principles of the worldview, the notion «qualitative characteristics of useful financial information» used in the «Conceptual Basis of Financial Reporting» [2] may be assigned to distinguish those types of accounting information or its state that will be the most suitable and useful for the main groups of users who use it for decision-making. The need to use this concept is based on two main provisions:

- accounting information on the financial statements of the enterprise can be used to make economic decisions by the subjects of management that increases the effectiveness of this process, as high-quality accounting information reduces information asymmetry and uncertainty; 
- based on the Fama hypothesis of the effectiveness of the financial markets, significant information on financial statements is immediately and fully reflected in the market value of the securities of the enterprise or group of enterprises, that was published it.

Accordingly, the use of the term «qualitative characteristics of useful financial information» in the scientific use, based on the two above assumptions, allows to determine the place and value of accounting information quality in the context of the enterprise management system and in the context of the functioning of financial markets.

3. The main value that influences the formation of ideals and norms of construction and justification of accounting scientific knowledge is an understanding of the positive effect of improvement of accounting information quality on the effectiveness of decisions taken by different subjects on its basis. Today, among scientists in the field of accounting there are no statements about the need to reduce the quality of accounting information, the refusal to take into account changing requests and the growing needs of users of accounting information.

Proceeding from this value, the main aim of accounting as a science is the search and development of new accounting information models, concepts and scientific theories that would ensure the improvement of accounting information quality or the provision of its necessary level.

4. Today, it is possible to single out some exemplary research results in the field of accounting information quality, which allow solving specific problems to find ways to improve it. For example, in 1991 a model for determining the level of non-discretionary accruals was developed [9], which was improved in 1995 [8]. It is widely used today to assess the quality of accounting information and is used in a significant number of scientific publications devoted to the problem of application of quality approach in accounting.

The conceptual level of the theoretical foundations of accounting information quality consists of various types of concepts that can be formed on the basis of existing approaches to understanding the essence of accounting information quality (conservative approach, accounting policy approach, procedural approach, quality management approach, risk approach, object-methodological approach, capital market approach, communication approach). If the paradigmatic level characterizes the general theoretical basis of accounting information quality, then at the conceptual level the features of understanding this concept in the context of a specific approach are revealed.

Depending on the chosen concept, an appropriate methodology for assessment of accounting information quality is constructed, taking into account the type of approach (process, system, object, subject) that is based on the concept, the type of the object with respect to which an appropriate level of quality and a set of criteria for compliance with the proper level of quality is established.

\section{SWOT analysis of research results}

Strengths. The strength of research is that the relationship between the basic theoretical constructs of the accounting information quality paradigm has been identified, taking into account the existence of three levels of application of the qualitative approach in accounting (the level of the national accounting system, the level of professional accounting organizations, the level of the enterprise) and possible means of quality control.

Weaknesses. The weak side is that to determine the level of accounting information quality based on the proposed formula, it is necessary to use data on the level of satisfaction of needs and expectations of users of accounting information that are not available in the enterprise accounting system and for which it is necessary to incur additional costs.

Opportunities. The opportunities for further research is the development of a universal approach for assessment of accounting information quality, given in the financial statements of enterprises, taking into account the modern features of the formation and development of the national accounting subculture.

Threats. The threats to the results of conducted research is the possibility of making changes in the current theoretical and methodological bases of accounting used in the study to form accounting information quality paradigm. In particular, when the structure of qualitative characteristics of accounting information is changed, they are presented in the converged conceptual basis of international financial reporting standards, the content of the basic elements of the developed accounting information quality paradigm should be clarified.

\section{Conclusions}

1. The necessity of identification of the theoretical bases that should be used to build an effective quality management system for accounting information in the enterprise is substantiated. Particularly, paradigmatic and conceptual level that form the accounting information space is used as a basis for building a system of scientific knowledge in the field of accounting information quality, and it is justified that the current quality paradigm influences the paradigm level, and the chosen approach to understanding the essence of accounting information quality - conceptual level.

2. It is determined that the basic theoretical constructs of the accounting information quality paradigm are: object; accounting information quality; characteristic of accounting information quality; user requirement. Based on the relationship between them, it is determined that accounting information quality is a measure of the compliance of accounting information characteristics over which the entity conducts and organizes accounting in order to meet the needs or expectations of users to the established requirements.

3. It is established that the conceptual level of the theoretical basis of accounting information quality is formed on the basis of the choice of a specific approach to understanding the essence of accounting information quality. Based on the communication approach, the construction of a qualitative accounting system at the enterprise is possible using three imperatives (accounting information users, accounting information quality, accounting information as an information product), which should be the basis for conducting scientific research in this field.

\section{References}

1. Salimova, T. A. Annotatsiia rabochei programmy distsipliny «Sovremennaia paradigma menedzhmenta kachestva» [Electronic resource] / T. A. Salimova. - Available at: \www/URL: http://www.mrsu.ru/ru/getfile.php?ID $=64104$ 
2. Kontseptualna osnova finansovoi zvitnosti [Electronic resource]: Concept from 01.09.2010. - Available at: \www/URL: http:// zakon3.rada.gov.ua/laws/show/929_009

3. Hohol, T. A. Oblikovo-analitychne zabezpechennia upravlinnia pidpryiemstv maloho biznesu [Text]: Monograph / T. A. Hohol. - Chernihiv: Vydavets Lozovyi V. M., 2014. - 384 p.

4. Plakhtii, T. Prichiny neobhodimosti obespecheniia kachestva uchetnoi informatsii [Text] / T. Plakhtii // Studia Universitatis Moldaviae. - 2016. - № 2 (92). - P. 126-131.

5. Plakhtii, T. Istorychnyi analiz rozvytku kontseptsii «yakisni kharakterystyky oblikovoi informatsii» [Text] / T. Plakhtii // Accounting and Finance. - 2016. - № 4 (74). - P. 60-68.

6. Pravdiuk, N. L. Quality of Accounting Information: Essence and Assessment Method [Text] / N. L. Pravdiuk, M. V. Pravdiuk // Accounting and Finance. - 2016. - № 2 (72). - P. 57-64.

7. Pushkar, M. S. Filosofiia obliku [Text]: Monograph / M. S. Pushkar. - Ternopil: Kart-blansh, 2002. - 157 p.

8. Dechow, P. Detecting Earnings Management [Text] / P. Dechow, R. Sloan, A. Sweeny // The Accounting Review. - 1995. Vol. 70, № 2. - P. 193-225.

9. Jones, J. J. Earnings Management During Import Relief Investigations [Text] / J. J. Jones // Journal of Accounting Research. 1991. - Vol. 29, № 2. - P. 193-228. doi:10.2307/2491047

10. Siegel, J. G. The «Quality of Earnings» Concept - A Survey [Text] / J. G. Siegel // Financial Analysts Journal. 1982. - Vol. 38, № 2. - P. 60-68. doi:10.2469/faj.v38.n2.60

11. Kuhn, T. S. The Structure of Scientific Revolutions [Text] T. S. Kuhn. - Ed. 3. - University of Chicago Press, 1996. 212 p. doi:10.7208/chicago/9780226458106.001.0001

12. Pro bukhhalterskyi oblik ta finansovu zvitnist v Ukraini [Electronic resource]: Law of Ukraine from 16.07.1999 № 996-XIV. Available at: \www/URL: http://zakon2.rada.gov.ua/laws/ show/996-14
13. Pro skhvalennia rozroblenykh Ministerstvom finansiv planiv implementatsii deiakykh aktiv zakonodavstva YeS u sferi bukhhalterskoho obliku ta audytu [Electronic resource]: Order of the Cabinet of Ministers of Ukraine from 08.04.2015№ 345-p. Available at: \www/URL: http://zakon2.rada.gov.ua/laws/ show/345-2015-p

\section{РАЗРАБОТКА БАЗОВЫХ ТЕОРЕТИЧЕСКИХ ОСНОВ КАЧЕСТВА УЧЕТНОЙ ИНФОРМАЦИИ}

Рассмотрены причины отсутствия парадигмы качества учетной информации в современных условиях. Предложена структура базовых теоретических основ качества учетной информации Выделены парадигмальный и концептуальный уровни качества учетной информации. Определены взаимосвязи между базовыми теоретическими конструкциями парадигмы качества учетной информации. Выделены императивы построения качественной учетной системы на основе использования коммуникационного подхода.

ключевые слова: качественный подход, качество в бухгалтерском учете, качество учетной информации, парадигма учета, парадигма качества учетной информации.

Pravdiuk Natalia, Doctor of Economic Sciences, Professor, Head of the Department of Accounting, Vinnytsia National Agrarian University, Ukraine, e-mail: pravduyk@mail.ru, ORCID: http:// orcid.org/0000-0003-0149-3612

Plakhtii Tetiana, PhD, Associate Professor, Department of Accounting and Taxation in the Economy, Vinnytsia National Agrarian University, Ukraine, e-mail: taniprof@mail.ru, ORCID: http://orcid.org/ 0000-0002-5379-1577

\section{Pashkevich M., Usatenko 0.}

\section{ECONOMIC ANALYSIS OF VENTURE ACTIVITY AT THE VENTURE ENTERPRISES}

Проведено дослідження сучасних методів економічного аналізу, за допомогою яких можливо проводити аналіз венчурної діяльності за кожною стадією життєвого циклу венчурного підприємства. Визначені методи аналізу, які враховують особливості кожної стадіi, ступень ризику, потребу у капіталовкладенні та дозволять запобігти помилок у планах і управлінських рішеннях, обрати правильну стратегію планування, виробництва, з відповідними обсягами випуску продукиї.

Ключові слова: венчурне підприємство, стадії життєвого циклу, методи економічного аналізу, стратегія планування.

\section{Introduction}

In the conditions of modern economic globalization, the existence and development of entrepreneurial activity is impossible without the presence of risk. If the entrepreneur does not take risks, he will lose income, lead to bankruptcy. The presence of a risk factor is a strong incentive for finding innovative ways of development, ways to save resources by entrepreneurs, should make them constantly carefully analyze their activities, their own projects, develop investment estimates and the like. The implementation of economic analysis has a great impact on the effectiveness of risky activities and contributes to achievement of its main goal - to maximize profits. From the results of eco- nomic analysis, the effectiveness of venture activity at all stages of venture enterprise life cycle depends on the different degrees of risk and needs in venture capital. Thus, the general problem of the research is in determination of methods for the economic analysis of venture activity of venture enterprises in the stages of their life cycle. This will contribute to the effectiveness of making risk management decisions due to the analytical support of venture activity.

\section{The object of research and its technological audit}

With the purpose of effective determination of methods of the economic analysis of venture activity of the 